\title{
DOE/me/ $25069-15$
}

MTCI 25069-102

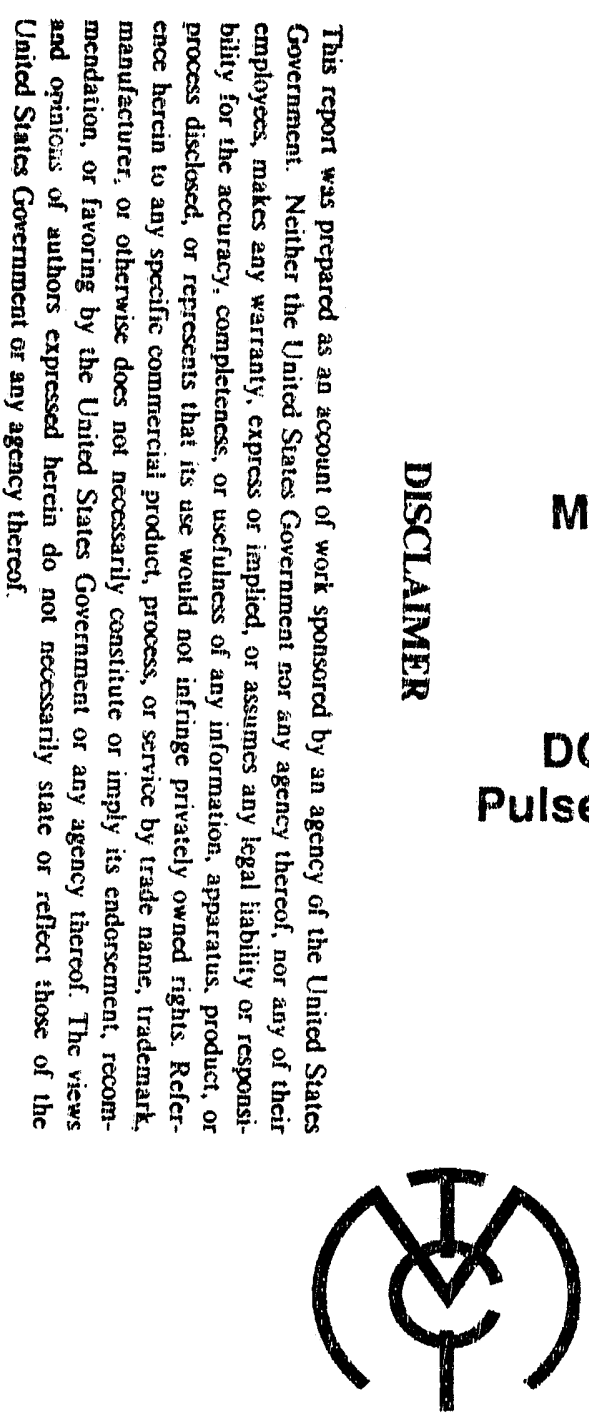

\section{TECHNICAL PROGRESS REPORT} May - July 1988 ,

For:

U.S. Department of Energy

Morgantown Energy Technology Center

Under:

DOE Contract No. DE-AC21-88MC246189?

Pulse Atmospheric Fluidized Bed Combustion

By:
DOE/MC/25069--15

DE92 017541

MANUFACTURING AND TECHNOLOGY CONVERSION

INTERNATIONAL, INC,

P.O. Box 21, Columbia, Maryland 21045

October 1988

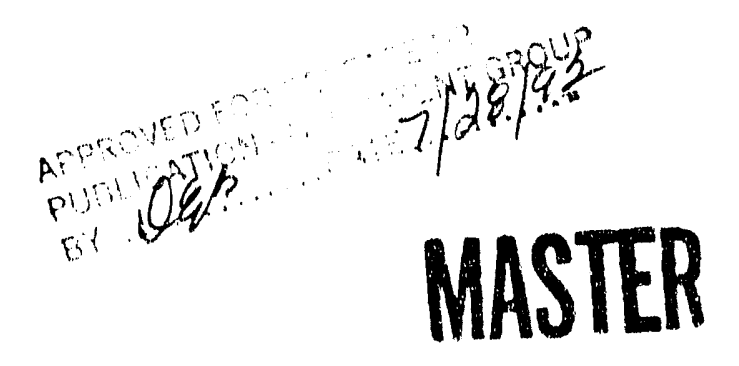

$\varepsilon \beta$ 


\section{PREFACE}

This first Quarterly Technical Progress Report presents the results of work accomplished during the period April 19 through July 24, 1988 under Contract No. DE-AC21-88MC25069 entitled "Pulsed Atmospheric Fluidized Bed Combustion (PAFBC).

The overall objective of the program is the development of a pulsed atmospheric fluidized-bed combustion (PAFBC) technology to burn coal and to provide heat and steam to commercial, institutional, and small industrial applications at a reasonable price in an environmentally acceptable manner. The program scope consisted of two tasks; the first was to establish preliminary feasibility by the use of theoretical and state-of-the-art information. This task was completed during the first quarter of the contract period and a topical report entitled, "Pulsed Atmospheric Fluidized Bed Combustion (PAFBC) - Preliminary Feasibility Study" was prepared as a "decision point to proceed" deliverable in accordance with the terms of the contract. This first quarterly progress report therefore covers the contract activities subsequent to the approval of the feasibility study and the decision to proceed with the Task 2 effort. As the initial quarterly technical progress report, this document includes a subsection on background which will be omitted in subsequent reports.

All effort during this period was devoted to the design and analysis of the PAFBC. Design drawings were prepared and fabrication and procurement initiated. Quotations were evaluated and a fabrication contract awarded. A site adjacent to the MTCI building was chosen for the installation of the PAFBC. Some ancillary components were purchased, renovated, and tested. Some delays in delivery of components have resulted in some schedule delay. It is anticipated that the program pace will accelerate as soon as parts are received and instaliation and assembly are initiated. 


\section{TABLE OF CONTENTS}

Page

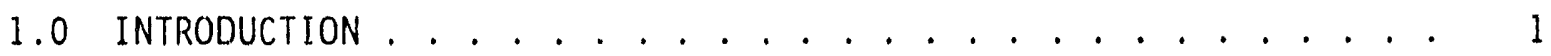

1.1 TECHNICAL OBJECTIVES ................ 2

1.2 TECHNICAL CHARACTERISTICS .............. 3

1.3 PAFBC SYSTEM . . . . . . . . . . . . . . 4

1.4 PULSE COMBUSTORS ................ 5

2.0 PROJECT DESCRIPTION AND WORK STATUS ............. 13

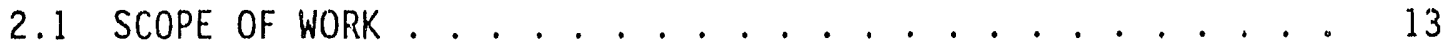

2.1.1 Task 1 - Feasibility............. 13

2.1.2 Task 2 - Laboratory-Scale Development
and Testing ................... 15

2.2 SUMMARY STATUS .................. 16

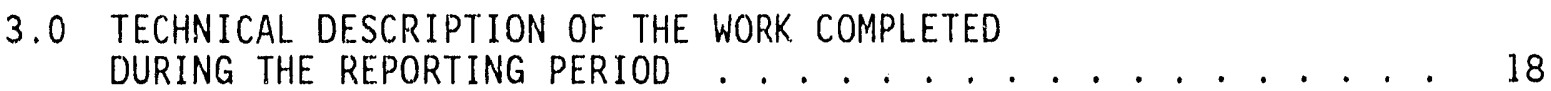

4.0 PLANS FOR THE NEXT PERIOD ............... 31 


\section{LIST OF FIGURES}

Page

FIgURE 1 SCHEMATIC OF A PULSE COMBUSTOR . . . . . . . . . . 7

FIGURE 2 PULSE COMBUSTION PRINCIPLE OF OPERATION $\ldots \ldots \ldots$

FIGURE 3 EFFECT OF AN INTENSE ACOUSTIC FIELD ON

THE BOUNDARY LAYER . . . . . . . . . . . . . 11

FIGURE 4 DESIGN DRAWING FOR FURNACE SECTION . . . . . . . . 21

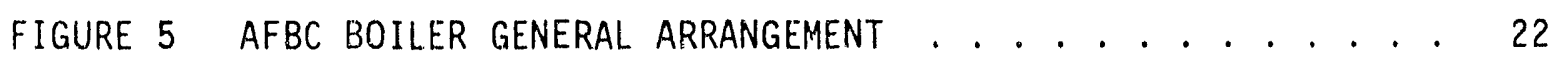

FIGURE 6 PROCESS FLOW DIAGRAM FOR THE INITIAL AFBC

SYSTEM DESIGN . . . . . . . . . . . . . . . . . 25

FIGURE 7 PROCESS FLOW DIAGRAM FOR THE MODIFIED AFBC

SYSTEM DESIGN . . . . . . . . . . . . . . . . . . 26

FiguRE 8 DRAWING OF THE TUBE LAYOUT IN THE BED SECTION . . . . . 28

FIGURE 9 GENERAL PERFORMANCE CURVE FOR ROOTS BLOWER . . . . . . 29

FIGURE 10 TEST SETUP USED FOR DETERMINING THE PERFORMANCE

OF THE ROOTS BLOWER ................ 30

\section{LIST OF TABLES}

TABLE 1 RESULTS OF THE PERFORMANCE TESTS OF THE ROOTS BLOWER . . . . . . . . . . . . 27 


\section{SECTION 1.0}

\section{INTRODUCTION}

Fluidized bed combustion technology has been developed in the U.S., England, and other countries to burn high sulfur coals in an efficient and environmentally acceptable manner. Demonstrations and commercial-scale Atmospheric Fluidized Bed Combustion (AFBC) systems have been built and operated successfully. In the basic concept, crushed coal is fed into a hot bed of dolomite/limestone that is fluidized by hot air. Water, pumped through coils immersed in the fluidized bed, is converted into steam for electricity, and/or process heat for other applications. Temperature in the bed is maintained at $1450-1750^{\circ} \mathrm{F}$. The low temperature of the fluidized bed reduces $\mathrm{NO}_{x}$ emissions. The sulfur present in coal is released as $\mathrm{SO}_{2}$, which is captured by the sorbent (dolomite or limestone) and converted into $\mathrm{CaSO}_{4}$. The spent sorbent $\left(\mathrm{CaSO}_{4}\right)$ may be regenerated and recycled continuously, or disposed of as solid waste along with the fly ash.

Although significant advancements have taken place regarding the design and operation of AFBC units of 50,000 - 100,000 pounds steam per hour capacity, the potential of AFBC technology has not been fully investigated for smal1-scale applications. The AFBC technology has a tremendous market potential in small-scale installations of less than 50,000 pounds steam per hour equivalents. These smaller units meet the needs for process heat, hot water, low-quality steam, and space heating for a wide variety of uses. Currentiy, oil-and natural gas-fired equipment are being used for these applications. Due to the large difference between the prices of these fuels and coal, a coal-fueled AFBC technology engineered for these sinali-scale applications has the potential of being very competitive. A successful coalfueled system will not only be less expensive, but will also lessen the nation's dependence on foreign oil and open up new markets for domestic coal. 


\subsection{TECHNICAL OBJECTIVES}

A significant opportunity to displace oil and natural gas usage exists in the industrial, commercial, institutional and residential sectors using coal in fluid bed combustors but this requires either an adaptation of the presently available technology or new concepts that address the economic.5, operational, and availability requirements of these end-use sectors for systems in the size range of 1,000 to $10,000 \mathrm{lbs} / \mathrm{hr}$ steam equivalent.

The technical characteristics of systems which can meet the objectives for entering these market sectors with packaged air heaters and boilers requires an $A F B C$ technology that can supply process heat, process steam, hot air, and hot water for small industries, commercial and residential buildings, warehouses, hospitals and other such users. These small units must produce clean energy from high sulfur coals at competitive prices. Innovative concepts and advanced $A F B C$ systems having the following characteristics are needed to meet this objective:

- High combustion efficiency

- High $\mathrm{SO}_{2}$ capture capacity

- Low $\mathrm{NO}_{x}$ emissions

- Reliability, maintainability and safety of operations equivalent to oil-and gas-fired packaged systems

- Compatibility with conventional heat and steam distribution and control technology

- Cost competitiveness with gas- and oil-fueled systems

- Capacities in the ranges of 1,000 - 10,000 1bs. steam per hour equivalent.

The scale-down of large systems will probably not meet these requirements and there is therefore a need for:

- Simplification of system configurations and methods of control

- Improvements in system start-up capability and load following 
- Enhanced system throughput with adequate pollution control and cost reduction

\subsection{TECHNICAL CHARACTERISTICS}

Fluid beds tend to have large thermal inertia. Start-up of large fluid bed systems requires a considerable amount of time and subsystems to preheat the beds in a controiled manner which adds to overall system cost and complexity. Such configurations and operational characteristics are more appropriate for base-loaded systems and are not satisfactory to small end-use sector applications due to cost and operational inadequacy. Concepts which provide for a simple design for fast start-up with low-cost hardware that also have simple operational characteristics is a must for small end-use sector applications. Thermal inertia of fluid beds also affects load following to some extent and this could be a serious shortcoming for small end-use applications. System designs must provide fast response to load changes, particularly through auxiliary firing subsystems and methods of bed heating. Such a design should not require additional hardware and control systems in order to maintain the system capital cost sufficiently low to compete favorably with the existing oil and gas equipment.

Scaling-down large AFBC systems to the size range for the end-use sectors of interest will result in complex and expensive systems that will not be competitive with presently available oil-and gas-fired equipment. In addition to the attributes discussed above, new design concepts that are aimed at the target market and end-use sectors must provide an opportunity for high throughput and pollution control requirements characteristic of the end-use applications contemplated. Higher throughput for a given combustor size will make a contribution to the reduction in capital cost per Btu/hr of fuel fired. This must be achieved, however, without compromising the pollution control performance of the equipment intended to meet fairly stringent requirements in some of these end-use applications. New concepts are therefore required that will enhance the combustion and sulfur removal reaction rates in the fluid bed beyond those found in conventional fluid-bed combustors without increase in NO $x$ production. These designs should also provide sufficient effluent 
pressure to allow the separation of particulate matter from the combustor effluent prior to exhausting it to the atmosphere without the need for complex mechanical systems. Other important attributes for these small systems should be reliability and ease of operation.

The MTCI Pulsed Atmospheric Fluidized Bed Combustion (PAFBC) system meets the above requirements and thus, has potential in developing into a viable technology which meets the reeds of small installations of various kinds. Incorporation of pulse combustion enhances combustion efficiency, $\mathrm{SO}_{2}$ capture capacity, and heat transfer efficiency of the fluidized bed. These benefits of pulse combustion result in smaller size PAFBC units of high throughput rates and lower costs when compared to conventional $A F B C$ units.

\subsection{PAFBC SYSTEM}

The MTCI concept for meeting the aforementioned technical objectives employs an auxiliary pulse combustor with a fluid-bed unit to achieve the performance, cost, and operational requirements of the contemplated end-use sector. There is no need for air fans. Simple configuration and control are obtained because:

- The combustor uses the coal fines to produce the pressure boost for the fluidization air.

- The fuel firing rate in the auxiliary pulse combustor controls the amount of induced fluidization air.

- The pulse combustor minimizes the use of expensive electricdriven blowers and is more reliable.

The pulse combustor also functions as the means by which rapid start-up of the fluid bed can be achieved with no need for other auxiliary subsystems for bed preheat for start-up. Rate of start-up can be very high by reducing the amount of induced fluidizing air during this transient due to the enhanced solid/gas heat transfer in the bed ( 1.5 to 2 times) resulting from the fluctuating pressure flow field. Also, load following is significantly superior due to the fast response of the auxiliary pulse burner. Enhanced 
combustion and sulfur adsorption reaction rates in the $A F B C$ are due to enhanced heat transfer and mass transfer in the near solid particle flow field. This enhancement is a direct result of the pressure fluctuations and flow oscillations generated from the pulse combustor. These pressure fluctuations are believed to be most effective in the low-frequency regime (50 - $150 \mathrm{~Hz}$ and cannot be economically achieved with other methods, i.e., air horns or electromagnetic devices). Experiments with other methods of excitation have failed to affect the reaction rates in a fluid bed significantly because of these primary factors.

First, higher frequencies tend to damp out in the fluid bed very quickly. This is due to the short wavelengths with small relative displacement amplitudes between the solids in the bed and the oscillating gas flow. Researchers mostly employed high frequencies due to the fact that high sound pressure levels can be achieved with high frequency by expending manageable amounts of energy when using air horns and electromagnetic devices. Second, excessive energy was required to achieve the necessary sound pressure levels at a more effective frequency range when such excitation was induced using compressed air horns and electromagnetic devices. This is not a problem with pulse combustion.

\subsection{PULSE COMBUSTORS}

Pulse combustors have the ability to produce large pressure fluctuations at the desired frequency range without the need for energy to compress air or supply the electricity in electromagnetic devices. This, in turn, provides for sufficient oscillations in the flow velocity of the fluid bed to enhance mass transfer and heat transfer in the bed. This is expected to improv oth combustion rate and the rate of sulfur capture in the bed while maintaining the bed temperature sufficiently low for suppression of $\mathrm{NO}_{\mathrm{X}}$. The pressure boost can also be employed to fluidize the bed and if desired operate a cyclone to separate particulate emissions from the AFBC effluent. With a high aerodynamic valve fluidic diodicity, the pressure drop for both fluidizing the bed and for particulate matter separation from the effluent of the AFBC (in a cyclone or a baghouse) can be supplied by the pulse combustor without the need 
for large fans or many moving parts. This increase in performance reliability reduces costs, simplifies operation, and increases throughput.

The pulse combustor is an extremely effective method for increasing heat transfer and combustion efficiencies via acoustic enhancement. Particles burning in an intense acoustic field have been shown to combust more rapidiy and transfer heat 150 to 250 percent more efficiently. As a cost-effective method for supplying the intense acoustic field within an FBC, the pulse combustor can provide phenomenal improvements in combustion and heat transfer efficiencies - beyond even the exceptional efficiencies already available in the FBC technology.

The pulse combustor is a compact, auxiliary burner with no moving parts (Figure 1) consisting of:

- Inlet tube

- Combustor chamber

- Flow diode

- Resonance tube

Fuel and air enter the combustor chamber (Figure 2). An ignition source (not shown) detonates the explosive mixture. The sudden increase in volume, triggered by the rapid increase in temperature and evolution of combustion products, pressurizes the chamber. As the hot gas expands, the flow diode permits preferential flow in the direction of the resonance tube.

Gases exiting the hot combustion chamber in the resonance tube possess significant momentum. A vacuum is created in the combustion chamber due to the inertia of the gases within the resonance tube. The inertia of the gases in the resonance tube permits only a small fraction of exhaust gases to return to the combustion chamber; the balance of the resonance gas exits, providing jet propulsion. Since the chamber pressure is below atmospheric pressure, air and fuel are drawn into the chamber where autoignition takes place. Agair, the flow diode constrains reverse flow, and the cycle begins anew. Once the first cycle is initiated, engine operation is self-perpetuating. 


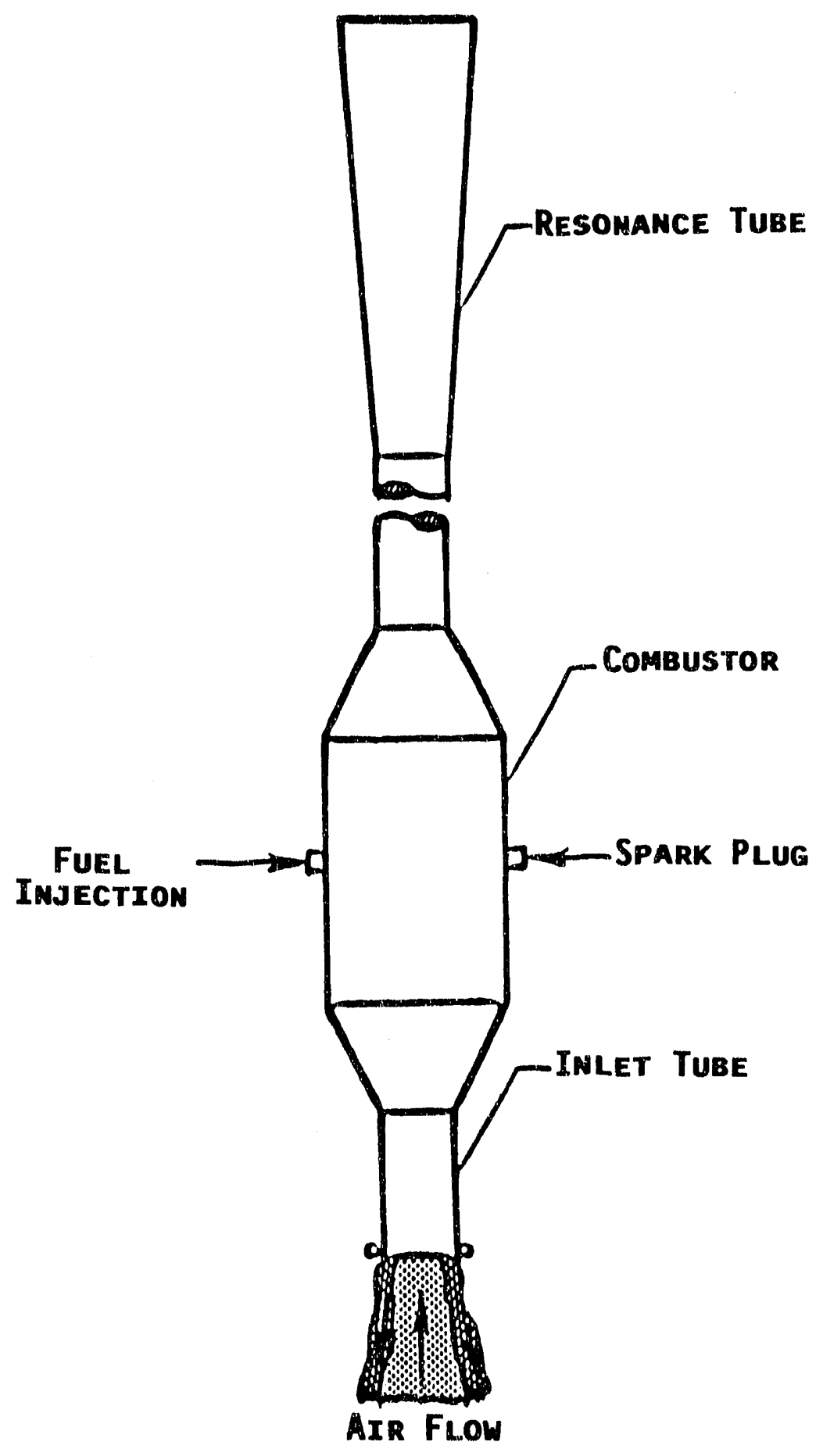

FIGURE 1: SCHEMATIC OF A PULSE COMBUSTOR 


\section{Combustion Chamber}

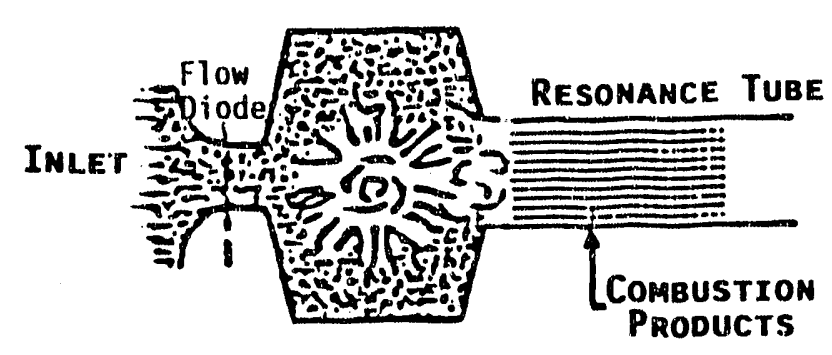

A. IGNITION AND COMBUSTION

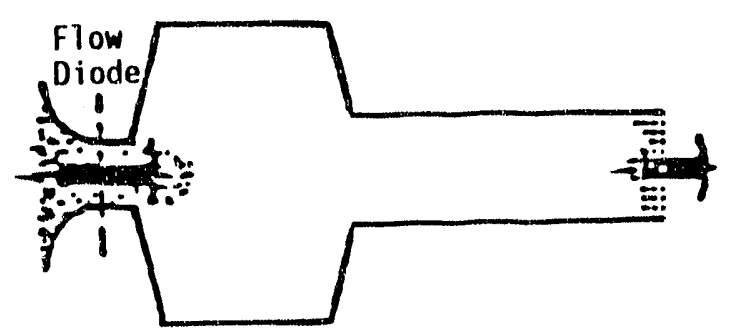

C. PURge AND RECHARGE

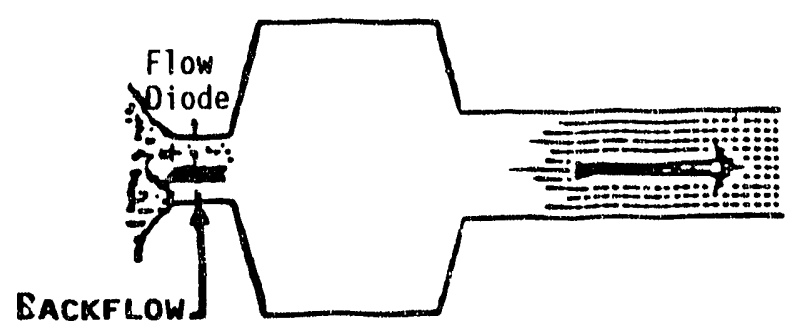

B. EXPANSION

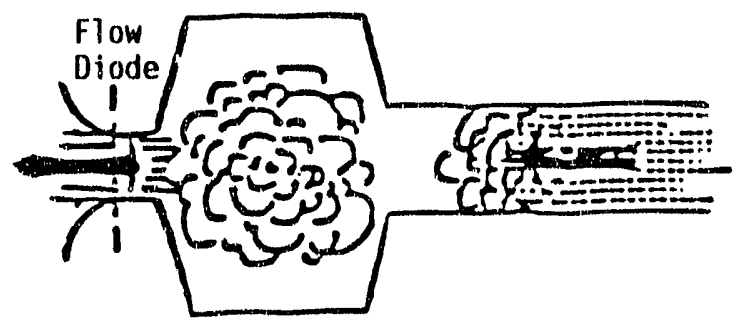

D. RECHARGE AND COMPRESS

FIGURE 2: PULSE COMBUSTION PRINCIPLE OF OPERATION 
MTCI's pulse combustors are designed for a much longer service life and have developed an aerodynamic valve without moving parts as an effective alternative for the flapper valve.

The flow diode utilized in many other pulse combustor concepts is a mechanical "flapper valve." The flapper valve is actually a check valve permitting flow from inlet to chamber, and constraining reverse flow by a mechanical seating arrangenent. This served quite well for the purpase intencled.

During the exhaust stroke, the bolndary layer builds in the reverse direction. Turbulent eddies chok off much of the reverse flow. Moreover, the exhaust gases are of a much higher temperature than the inlet gases. Therefore, the viscosity of the gases is much higher and the reverse resistance of the inlet diameter, in turn, is much higher than forward flow through the same opening (unlike liquids, gases exhibit a marked increase in viscosity with temperature rise). These phenomena along with the high inertia of the exhausting gases in the resonance tube combine to yield preferential and mean flow from inlet to exhaust. Thus, the nonmechanical pulse combustor is a self-aspirating engine, drawing its own air and fuel into the combistion chamber and auto-ejecting combustion products. A wide tolerance of operating parameters gives excellent turndown ratios up to 20 . Turndown ratio is the ratio of design capacity divided by lowest operating capacity. This enables the pulse combustor to operate from substoichiometric to superstoichiometric regimes. These attributes allow great system flexibility. While operating in a superstoichiometric mode, the pulse combustor functions as a nonmechanical air pump.

MTCS has obtained 400 percent excess air operation in an existing pulse combustor. With proper thrust augmenters, much more air than what is needed by PAFBC can be pumped.

The rapid pressure oscillations in the combustion chamber (from 25 psia to subambient on the order of 100 times per second) generate an intense oscillating flow field. This oscillating flow field effectively scrubs the 
boundary layer away from the burning particles (Fiqure 3). In the process of pulsating combustion or combustion-induced flow oscillations, much of the diffusion limitation is removed. These reactors tend to achieve high-pressure fluctuations and high-velocity flow oscillations. This results in an number of beneficial combustion process advantages that enhance system performance. In the case of coal combustion, the fluctuating flow field causes the products of combustion to be swept away from the reacting solid, thus providing access to oxygen with little or no diffusion limitation. Second, pulse combustors experience very high mass transfer and heat transfer rates within the combustion zone. While these reactors tend to have very high heat release rates ( 6 to 8 times those of conventional burners), the vigorous mass transfer and high heat transfer within the combustion region do result in a more uniform temperature. Thus, peak temperatures attained are much lower than in the case of conventional systems. This results in significant reduction in nitrogen oxide formation.

The enhanced access by oxygen to the other reactants in pulse combustion reduces the need for both significant excess air operation and higher reactor temperature. The high heat release rates also result in a smaller reactor size for a given rate of material processed. Therefore, there is a significant reduction in the residence time required. Similar enhancement of heat and mass transfer rates can also be expected in tine $F B C$, due to the acoustic enhancement transmitted to the bed from the pulse resonance tubes. The bubble sizes are expected to be smaller in the pulse fluid bed than in the regular fluid bed.

Another benefit with pulse combustors is the fact that they aspirate their own combustion air. The amount of air aspirated is a function of the firing rate of the burner and the aerodynamic valve fluidic diodicity and is automatically adjusted by fuel feed rate. Pulse combustors do not require combustion air fans nor do they require controls to coordinate the mass flow rates of fuel and combustion air. These combustors also develop an induced mean pressure boost within the combustion chamber and expel the products of combustion at high kinetic energy levels (in the order of $600-800 \mathrm{ft} / \mathrm{sec}$ ). 
1) Diffusion Limited Process

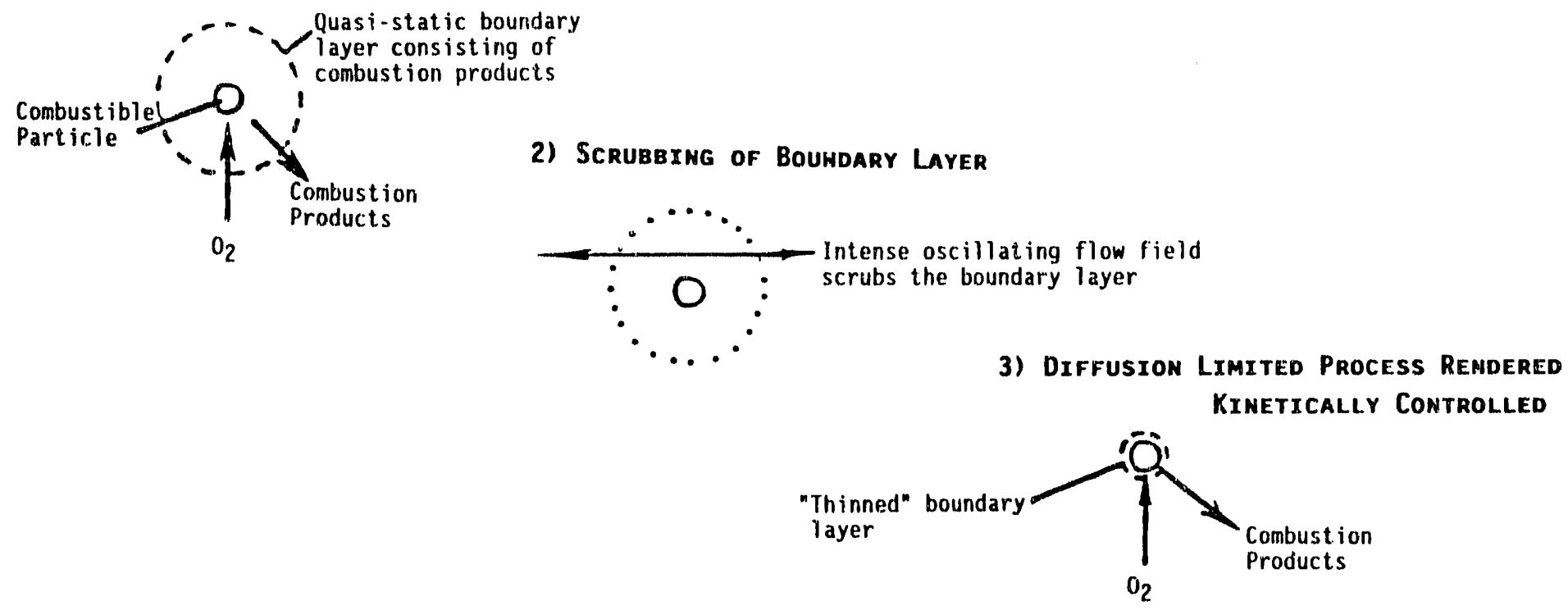

\section{FIGURE 3: EFFECT OF AN INTENSE ACOUSTIC FIELD \\ ON THE BOUNDARY LAYER}


The kinetic energy, which is totally combustion-induced with no mechanical systems required, can be employed to aspirate more air through a venturi section for supply of fluidization air if necessary. 


\section{SECTION 2.0}

\section{PROJECT DESCRIPTION ARD WORK STATUS}

The overall objective of the program is to develop the pulsed atmospheric fluidized-bed combustion (PAFBC) technology to burn coal and to provide heat and steam to commercial, institutional, and small industrial applications at a reasonable price in an environmentally acceptable manner. This overall objective will be met by performing a number of tasks at two different levels.

The Task 1 objective is to establish preliminary feasibility by the use of theoretical and state-of-the-art information. The Task 2 objective is to build and experimentally establish operability and performance of the PAFBC for different types of coal.

\subsection{SCOPE OF WORK}

\subsubsection{TASK 1: FEASIBILITY}

Subtask 1.1: Evaluation - The Contractor shall perform evaluation of state-of-the-art information on atmospheric fluidized-bed combustor (PAFBC) technology and pulsed combustion of coal. The Contractor shall review relevarit published data and evaluate it for use in the feasibility study. Data on coals, sorbents, $\mathrm{SO}_{2}$ and $\mathrm{NO}_{x}$ control, characteristics of fluidized-bed coal combustors, pulsed combustion of coals, regeneration of spent sorbents, steam generation, ash disposal, and other aspects shall be used to formulate a design basis for the study.

Subtask 1.2: Market Analysis - For the new technology, the Contractor shall identify potential markets for generating heat and steam for different uses and shall make projections on the increased use of coal. The contractor shall assess the competition from oil-and gas-fired units. 
Subtask 1.3: Conceptual Design and Cost Estimate - Using the design basis formulated in Subtask 1.1, the Contractor shall develop a conceptual design of a PAFBC system that will product $1,0001 \mathrm{bs} / \mathrm{hr}$ of steam equivalent. The Contractor shall prepare a preliminary cost estimate and shall compare the cost of the proposed system with the cost of oil-and gas-fired units currently in use.

Subtask 1.4: Test Plan for Task 2 Work - The Contractor shall ident ify problematic aspects of the technology and develop a test plan to resolve the problems through theoretical and experimental approaches. The Test Plan shall be submitted to the DOE/Contracting Officer's Technical Representative (COTR) for review and approval.

Subtask 1.5: Task 1 Topical Report - A Topical Report shall be prepared summarizing the PAFBC package boiler concept. The report shall include market, technical, design and cost information developed under Subtasks 1.1, 1.2, and 1.3, and the Test Plan developed under Subtask 1.4. The report shal1 include a review of the coal/sorbent feed, ash handling and cleanup systems, and the sensitivity of these factors on environmental system capital and operating and maintenance costs. The report shall also address the system's potential for meeting the following criteria and provide the material required to proceed to the performance of Task 2:

- The PAFBC combustor and controls technology must be competitive with gas-/0il-fired technology and scaleable to the 1,000 $1 \mathrm{~b} / \mathrm{hr}$ steam equivalent range.

- The solids handling problems must be amenable to automated dust-free operation.

- Overall emissions $\left(\mathrm{SO}_{2}, \mathrm{NO}_{x}\right.$, and particulates) must be comparable to those of conventional gas-/0il-fired equipment.

- The PAFBC system must require no operating or maintenance skills beyond those needed to operate equivalent gas-/0il-fired equipment. 
Subtask 1.3: Conceptual Design and Cost Estimate - Using the design basis formulated in Subtask 1.1, the Contractor shall develop a conceptual design of a PAFBC system that will product $1,000 \mathrm{lbs} / \mathrm{hr}$ of steam equivalent. The Contractor shall prepare a preliminary cost estimate and shall compare the cost of the proposed system with the cost of oil- and gas-fired units currently in use.

Subtask 1.4: Test Plan for Task 2 Work - The Contractor shall identify problematic aspects of the technology and develop a test $p 1$ an to resolve the problems through theoretical and experimental approaches. The Test Plan shall be submitted to the DOE/Contracting Officer's Technical Representative (COTR) for review and approval.

Subtask 1.5: Task 1 Topical Report - A Topical Report shall be prepared summarizing the PAFBC package boiler concept. The report shall include market, technical, design and cost information developed under Subtasks 1.1, 1.2, and 1.3, and the Test Plan developed under Subtask 1.4. The report shall include a review of the coal/sorbent feed, ash handling and cleanup systems, and the sensitivity of these factors on environmental system capital and operating and maintenance costs. The report shall also address the system's potential for meeting the following criteria and provide the material required to proceed to the performance of Task 2:

- The PAFBC combustor and controls technology must be competitive with gas-/0il-fired technology and scaleable to the $1,000 \mathrm{lb} / \mathrm{hr}$ steam equivalent range.

- The solids handling problems must be amenable to automated dust-free operation.

- Overall emissions $\left(\mathrm{SO}_{2}, \mathrm{NO}_{\mathrm{x}}\right.$, and particulates) must be comparable to those of conventional gas-/oil-fired equipment. 
- The PAFBC system must require no operating or maintenance ski11s beyond those needed to operate equivalent gas-/oil-fired equipment.

- A significant market potential must exist for the integrated PAFBC technology.

\subsubsection{TASK 2: LABORATORY-SCALE DEVELOPMENT AND TESTIMg}

The testing specified in these subtasks will be conducted in accordance with the approved Test Plan.

Subtask 2.1: Design, Procurement, and Construction of an Atmospheric Eluidized-Bed Combustor - The Contractor shall design, procure, and build a fluidized-bed system with the following features:

Capacity:

Fluidizing Velocity:

Sorbent:

Coal:
1,000 lbs stear:/hr

$5-10 \mathrm{ft} / \mathrm{sec}$

Precalcined dolomite or limestone

Bituminous/Sulfur Content: 2 - $4 \%$

Temperature of Operation: $1400-1750^{\circ} \mathrm{F}$

Subtask 2.2: Coal Combustion Tests in the PAFBC System - The Contractor shall carry out coal combustion tests under a range of conditions as set forth in the approved Test Plan to establish baseline performance data. Tests shall be carried out under the following conditions:

$\begin{array}{ll}\text { Superficial Velocity: } & 5-10 \mathrm{ft} / \mathrm{sec} \\ \text { Temperature: } & 1400-1750^{\circ} \mathrm{F} \\ \text { Pressure: } & \text { Near Atmospheric } \\ \text { Mode of Operation: } & \text { Batch with respect to sorbent and } \\ & \text { continuous with respect to coal } \\ \text { Coal: } & \text { Bituminous/Sulfur Content: } 2-4 \% \\ \text { Sorbent: } & \text { Precalcined dolomite or 1imestone } \\ \text { Ca/S: } & 2-4\end{array}$


The Contractor shall use the test data to optimize operational parameters with respect to fluidization velocity, sorbent/coal ratio, temperature of operation, combustion efficiency, steam generation, $\mathrm{NO}_{\mathrm{x}}$ control and sulfur capture, and establish optimum operational parameters and baselire performance data.

\section{Subtask 2.3: Modification of PAFBC System for Pulsed Combustion of}

Coal - The Contractor shall modify the PAFBC system by the incorporation of a pulse combustor that supplies pulsed effluent gas to fluidize the bed. The needed modifications and the geometry of the pulsed PAFBC combustor shall be as determined under Subtask 1.3 study.

Subtask 2.4: Operation of the Pulsed PAFBC Without Coal - The Contractor shall operate the fluidized-bed combustor in the pulsed mode to establish fluidization parameters under pulsing conditions and determine the effect of pulsations on fluidization velocity, bed expansion, and particle elutriation at optimum conditions for fluidization under pulsed conditions.

Subtask 2.5: Coal Combustion Tests in the PAFBC System - The Contractor shall carry out coal combustion tests under a range of conditions established under subtasks 2.1 and 2.4, generating test data to evaluate operability, performance and pollution control efficiency of the PAFBC system, and optimization of design and operational parameters.

Subtask 2.6: Technical, Environmental, and Economic Assessment - The Contractor shall perform technical, environmental, and economic evaluations based on experimental data generated under Subtasks 2.2, 2.4, and 2.5.

\subsection{SUMMARY STATUS}

Al1 effort during this period was devoted to the design and analysis of the PAFBC. Design drawings were prepared and fabrication and procurement initiated. Quotations were evaluated and a fabrication contract awarded. A site adjacent to the MTCI building was chosen for the installation of the PAFBC. Some ancillary components were purchased, renovated, and tested. Some 
delays in delivery of components have resulted in some schedule delay. It is anticipated that the program pace will accelerate as soon as parts are received and installation and assembly are initiated.

Computer programs using Lotus 1-2-3 spreadsheet have been developed at MTCI to analyze the operational characteristics of the PAFBC. An optimal configuration and some preliminary operational characteristics of the PAFBC, based on the stated design criteria, have been determined.

The atmospheric fluidized bed combustor steam generator is designed to burn low-quality, high ash and sulfur content coal. It is capable of generating $1.1 \mathrm{MMBtu} / \mathrm{hr}$ of steam at a temperature of $270^{\circ} \mathrm{F}$, and a pressure of 42 psia. 


\section{SECTION 3.0 \\ TECHNICAL DESCRIPTION OF THE WORK \\ COMPLETED DURING THE REPORTING PERIOD}

A preliminary system design of an atmospheric fluidized bed combustor, capable of generating $1,000 \mathrm{lb} / \mathrm{hr}$ steam was initiated. The design criteria for the proposed atmospheric fluidized bed combustor were as follows:

- The freeboard should allow for particle disengagement and provide a minimum residence time of three (3) seconds.

- Heat removal in freeboard should be minimized to promote complete combustion.

- Flexible heat removal system should be incorporated to allow a wide range of turn down.

- System height should be limited to less than 15 feet.

- Unit should be shop fabricated and truck transportable to the greatest extent possible.

- Design geometry should minimize accumulation of ash and particulates.

- Particulate collection should be localized at minimum number of points.

- System should consist of simple modular construction. 
Computer programs using Lotus 1-2-3 spreadsheet have been developed at MTCI to analyze the operational characteristics of the PAFBC. An optimal configuration and some preliminary operational characteristics of the PAFBC, based on the stated design criteria, have been determined.

The atmospheric fluidized bed combustor steam generator is designed to burn low-quality, high ash and sulfur content coal. It is capable of generating $1.1 \mathrm{MMBtu} / \mathrm{hr}$ of steam at a temperature of $270^{\circ} \mathrm{F}$, and a pressure of 42 psia.

The fluidized bed is approximately three feet deep and four square feet in area. Horizontal boiler tubes are mounted within the bed to maintain the bed temperature between $1500^{\circ} \mathrm{F}$ and $1600^{\circ} \mathrm{F}$. The bed contains four separately manifolded tube bundles formed from 1 1/2" sch 80 S.S. 304 pipe. The tubes are arranged in a triangular pitch, four pass arrangement. Each tube pass is 21 inches lorig, and the total heat transfer area is $14 \mathrm{ft}^{2}$.

The boiler tubes are mounted in such a way as to obtain a uniform temperature within the bed. Two of the tube bundles are both verticaliy and orthogonally displaced within the bed relative to the other two tube bundies. About 70 percent of the total steam is generated within the bed section, and the remaining is generated in the convection section. Six feet of expanded disengagement. height above the fluidized bed allows for the disengagement of solids entrained by the bed fluidization action.

The combustion gases exit the AFBC at a temperature of approximately $1600^{\circ} \mathrm{F}$ and atmospheric pressure. The hot gases enter the convective section, where additional heat is transferred to the boiler tubes. The tube bundle in the convection section consists of $11 / 2^{\prime \prime} \mathrm{sch} 40 \mathrm{C} . \mathrm{S}$. pipes. The tubes are arranged in a square pitch, with 6 tubes per row in an 18-pass arrangement. The tubes are 62 inches long from weld to weld and are supported by a vertical tube sheet. The tube sheet face is sealed with an additional tube sheet cover. The total heat transfer area is $233 \mathrm{ft}^{2}$. 
The flue gases exit the convection section at approximately $500^{\circ} \mathrm{F}$ and enter a cyclone. The design configuration for the AFBC is shown in Figure 1. The AFBC is constructed in three separate sections: 1) Furnace section, 2) Transition Duct, and 3) the Down Flow Convection section.

\section{Furnace Section}

Figure 4 is a drawing of the furnace section. The furnace is constructed in four separate sections. These include: 1) a convergent lower section; 2) an intermediate section of dimensions $34^{\prime \prime} \mathrm{W} \times 34^{\prime \prime} \mathrm{L} \times 36^{\prime \prime} \mathrm{H}$; 3) a $36^{\text {" high }}$ expanded section with lower dimensions of $34^{\mathrm{W}} \mathrm{W} \times 34^{\mathrm{I}} \mathrm{L}$, and upper dimensions of 34 "W $\times 58$ "L; and 4) an upper section of dimensions $34 " \mathrm{~W} \times 58 " \mathrm{~L} \times 36$ " $\mathrm{H}$. Each section is provided with mating $f l$ anges and is con ructed from $1 / 4$ " carbon steel plate. The furnace super structure or frame, shown in Fiqure 5 , is formed from welded $3 "$ angle iron located on the outer surface of the $1 / 4$ " plate.

Each section is internally lined with a double layer of castable refractory. The outer insulating layer is $3^{\prime \prime}$ thick, and consists of a light weight insulating castable with a density of $41 \mathrm{lb} / \mathrm{ft}^{3}$, and a $K$ value of $1.25 \mathrm{Btu} . \mathrm{in} / \mathrm{ft}^{2} /{ }^{\circ} \mathrm{F} / \mathrm{hr}$, at $1500^{\circ} \mathrm{F}$. The inner section is $2^{\prime \prime}$ thick and consists of an abrasion resistant, dense castable refractory, with a density of $118 \mathrm{lb} / \mathrm{ft}^{3}$, and a $\mathrm{K}$ value of $5.6 \mathrm{Btu} . \mathrm{in} / \mathrm{ft}^{2} /{ }^{\circ} \mathrm{F} / \mathrm{hr}$, at $1500^{\circ} \mathrm{F}$. The total heat lost from the furnace walls is less than 5 percent of the total input heat. The refractory is anchored with a sufficient density of anchors to ensure adherence to the furnace walls.

The upper furnace section is provided with a circular connection flange for the centrally located pulse combustor, and a rectangular flange for the transition duct. The lower furnace section is provided with a circular flange as an outlet means for discharging solids contained in the furnace under normal operation. 


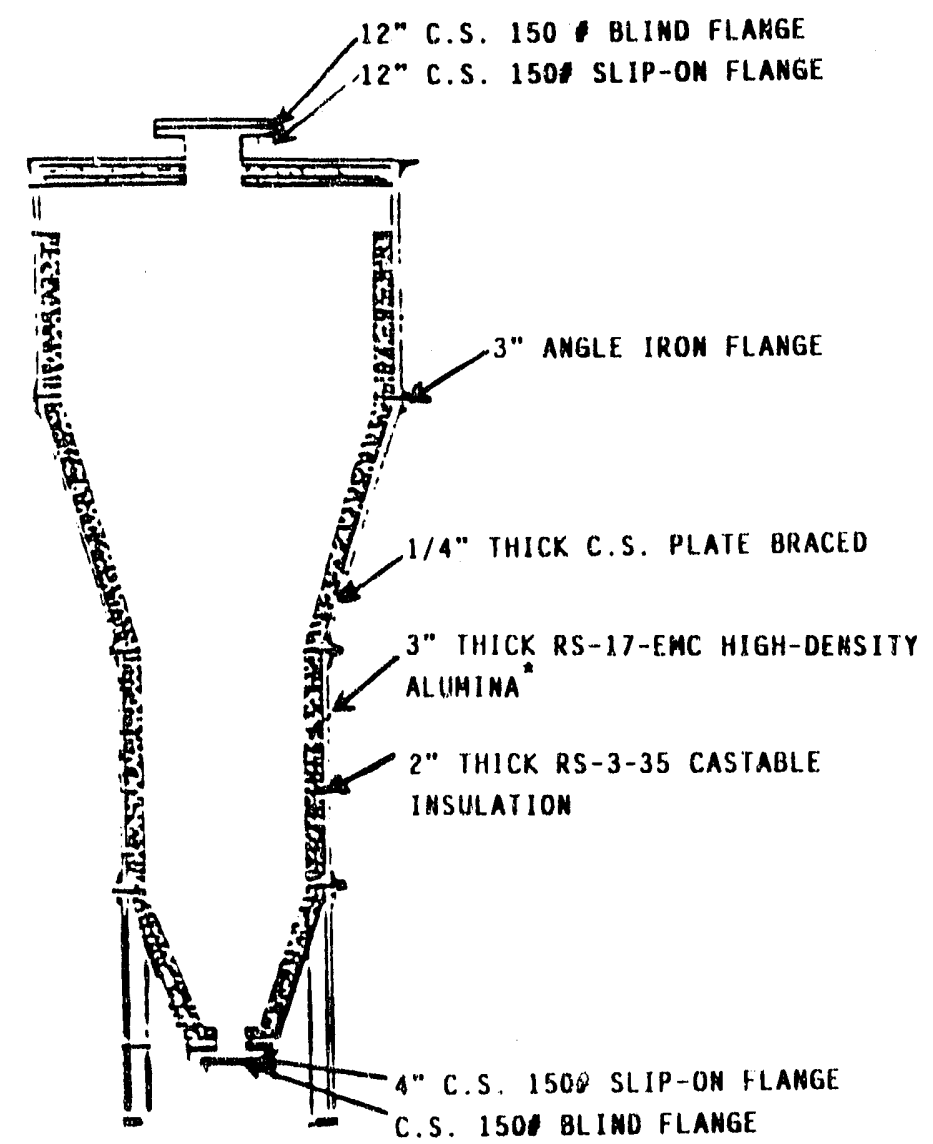

Right Side Viem of Furmace

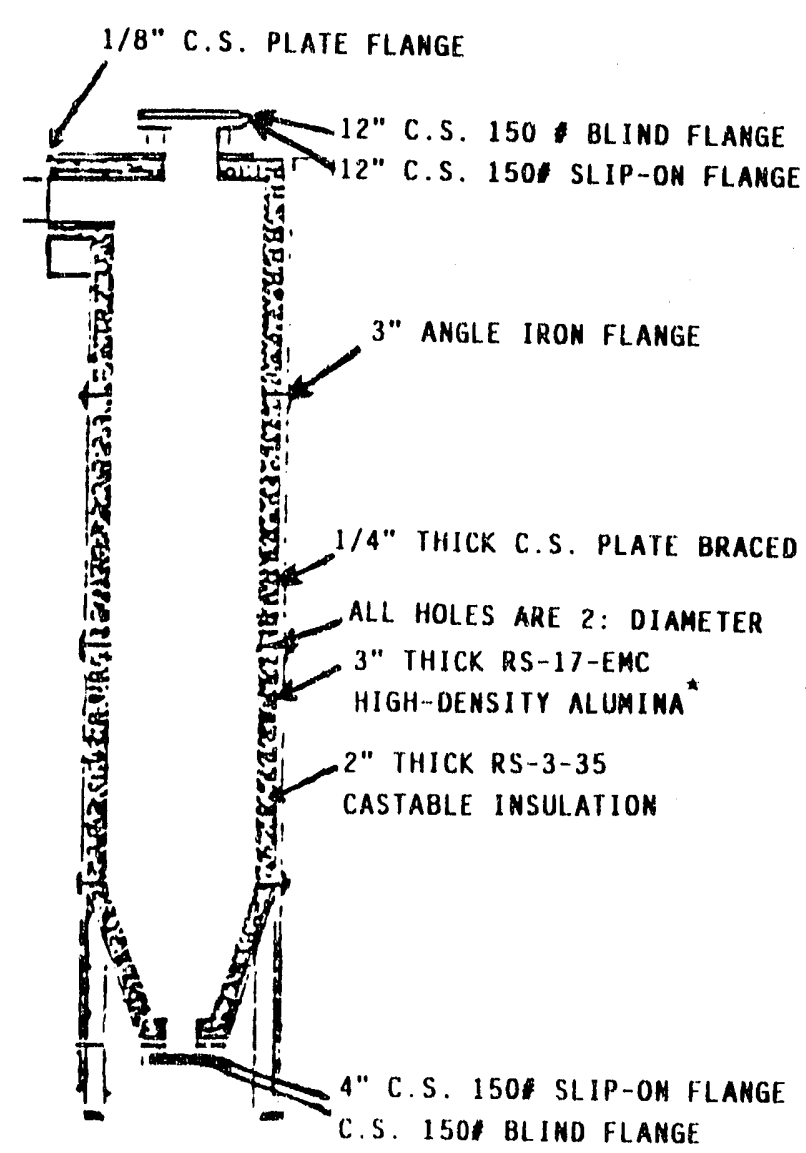

Back and front View of Furmace

\footnotetext{
"Refractory materials are by:

Pyro Engineering, Santa Fe Springs, CA
} 


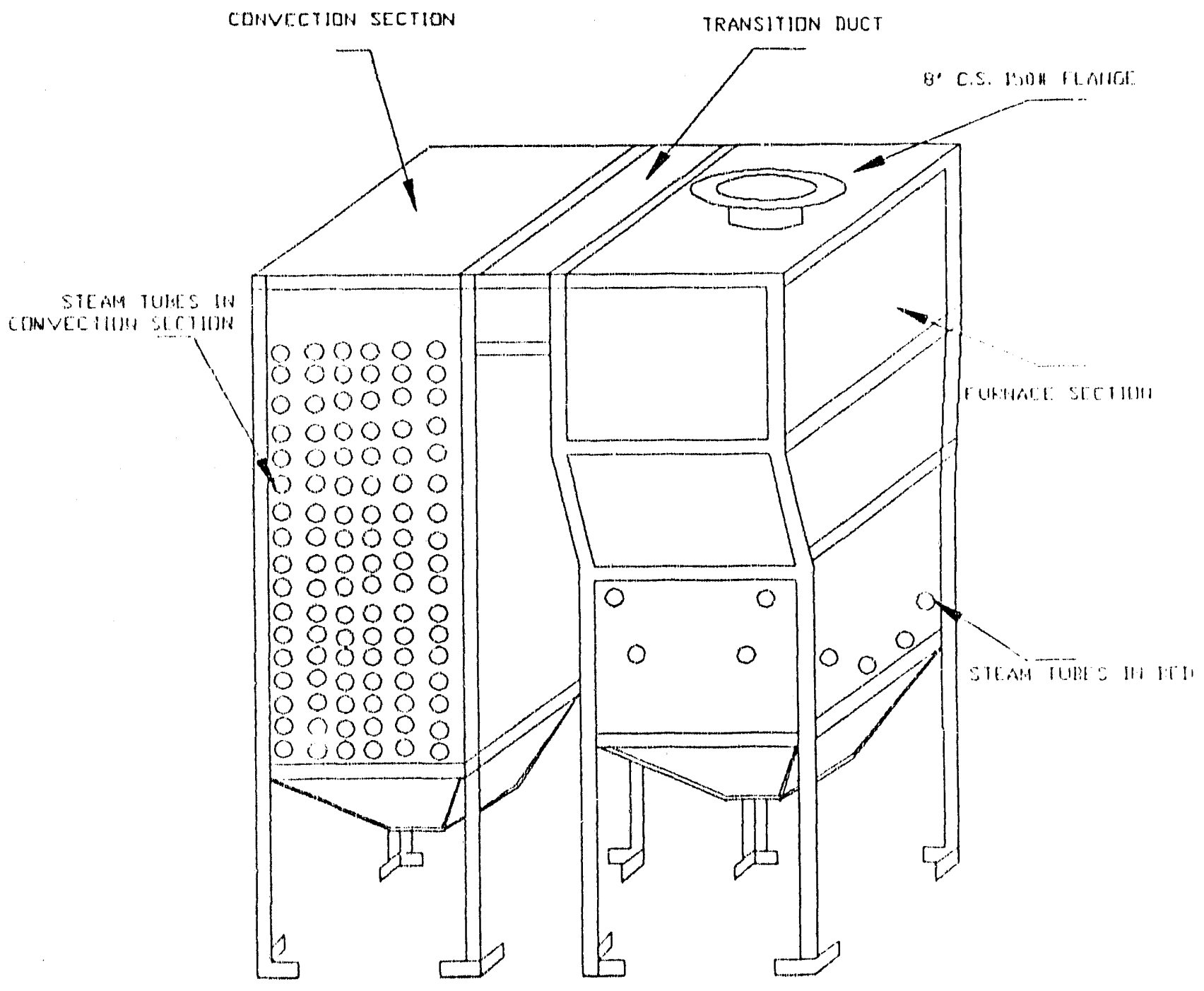

FIGURE 5: AFBC BOILER GENERAL ARRANGEMENT 


\section{Transition Duct and Convective Section}

A design for the transition duct and convective section was completed. The transition duct is constructed from $1 / 4$ " carbon steel plate, with rectangular flanges at both ends for connection to the furnace section and the convection section. The transition section is insulated with $3^{\prime \prime}$ thick, lightweight insulating castable. Total length of the transition section is $2 \mathrm{ft}$ long, with a flue gas passage cross sectional area of 2.2 square feet.

The convection section consists of three separate sections: 1) the lower convergent section, 2) the main body, and 3) the upper section. Each section is constructed from $1 / 4$ " carbon steel plate with mating flanges provided. The upper convection section is provided with a flanged inlet means for connecting to the transition duct. The lower convection section is provided with a circular flange as an outlet means for ash collection, and a rectangular flanged outlet for exiting flue gas. The main body houses the steam generation tube bundles. An inspection port is provided to check the tube bundles periodically, and to clean the tubes from accumulated solid deposition during the operation. An end cover is provided for the tube bundles. It is constructed from 1/8" carbon steel plate, with 1 " thick ceramic fiber insulation. The convection section is lined with a single layer of insulating castable refractory. The insulating layer is 3" thick, and consists of a lightweight insulation castable with a density of $41 \mathrm{lb} / \mathrm{ft}^{3}$, and a $\mathrm{K}$ value of $1.25 \mathrm{Btu} . \mathrm{in} / \mathrm{ft}^{2} / \mathrm{F} / \mathrm{hr}$ at $1500^{\circ} \mathrm{F}$.

The initial design drawings were provided to four separate vendors for quotation. Each vendor provided MTCI with quotations for fabricating the furnace section and the convection section, separately. Review of the quotations revealed that fabrication of the convection section would approximately double the overall system cost. Since the primary objective of this work is to investigate the integration of a pulse combustor with the fluidized bed portion of the furnace, and since the convection section does not incorporate any novel component technology, the additional expense for the convection section was considered to be unjustified and the convection section will be replaced by a direct quench scrubber. This method of cooling 
the hot flue gases from the furnace section is anticipated to be significantly less costly, and several existing components in MTCI's facility can be utilized in constructing this system. This modification involves no significant changes in the combustor furnace itself, and the unit will have the same operational characteristics as previously described. However the usable steam output of the modified system will be reduced to $700 \mathrm{lb} / \mathrm{hr}$ compared to $1000 \mathrm{lb} / \mathrm{hr}$ for the boiler system which includes a convective steam generator. Note that a convection section may be added later, if desired, thereby increasing the steam generation capacity to $1000 \mathrm{lb} / \mathrm{hr}$.

Figures 6 and $\underline{Z}$ show the process flow diagram for the initial AFBC system design and the modified $A F B C$ system design, respectively.

Based on the quotation received from four separate vendors, MTCI selected a qualified vendor (SEC Construction corporation) for fabricating the furnace section. The final mechanical drawings of the furnace section were provided to the vendor and it is anticipated that the fabrication of the furnace section will be completed early next quarter.

There were some subsequent minor changes to the initial furnace design. The thickness of the outer castable refractory insulating layer has been changed from 3 " to 2" and also the thickness of the inner, high density, abrasion resistant castable refractory has been changed from 2" to 3 ". This change was made after consulting with the refractory professionals who suggested that, since the abrasion resistant castable refractory is subjected to higher thermal cycling, it should be made thicker than 2" to avoid possible cracking. Two 4" ports have been added to the furnace section. One is $1 \mathrm{ft}$ above the bed and the other one is $1 \mathrm{ft}$ above the distributor plate. These ports will be used either as the feeding port for coal and limestone or as a port to connect an outside burner for initial bed heat up. A 4" port has also been added to the lower convergent section as an inlet port for fluidization air. 


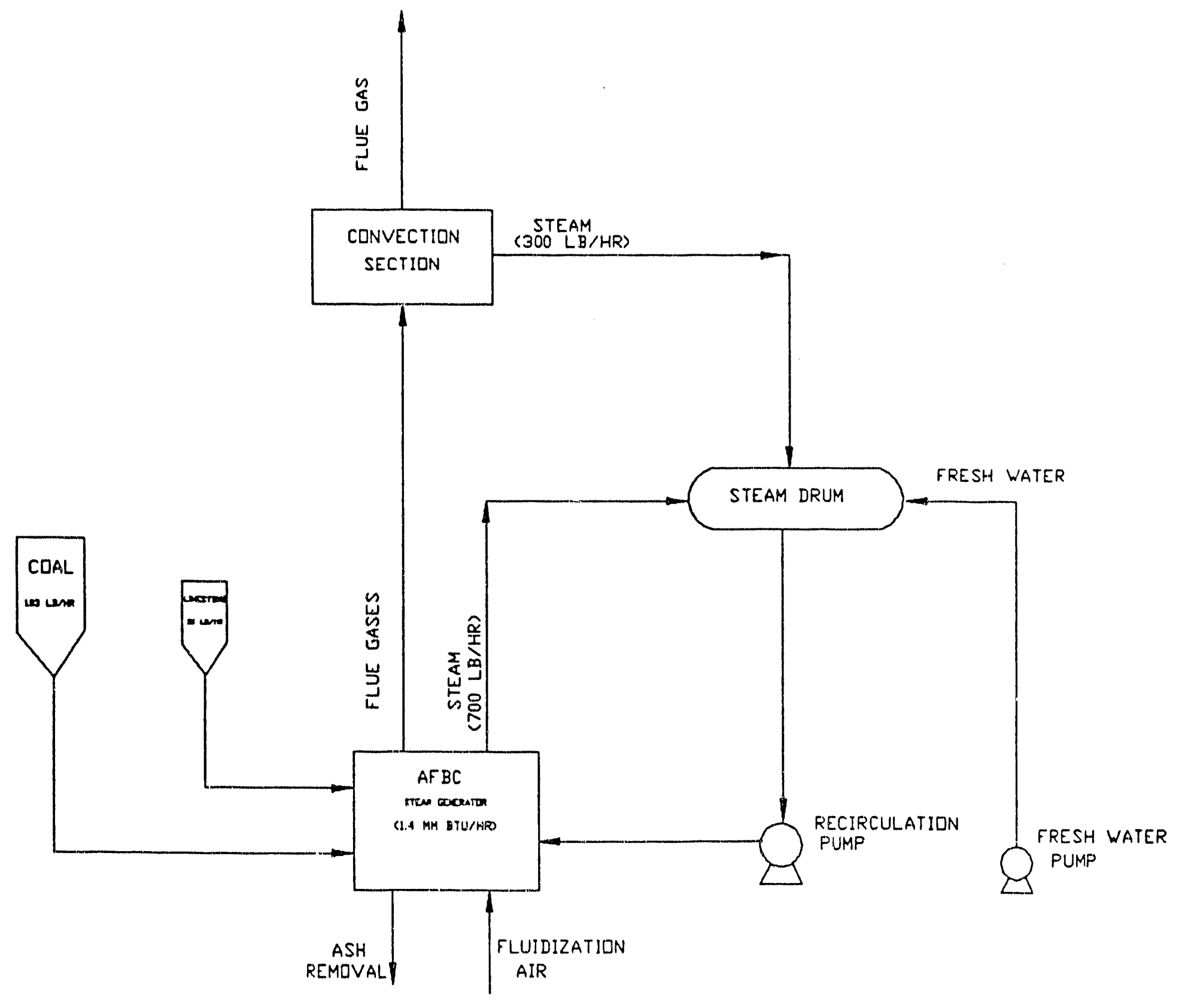

FIGURE 6: PROCESS FLOW DIAGRAM FOR THE INITIAL AFBC SYSTEM DESIGN 


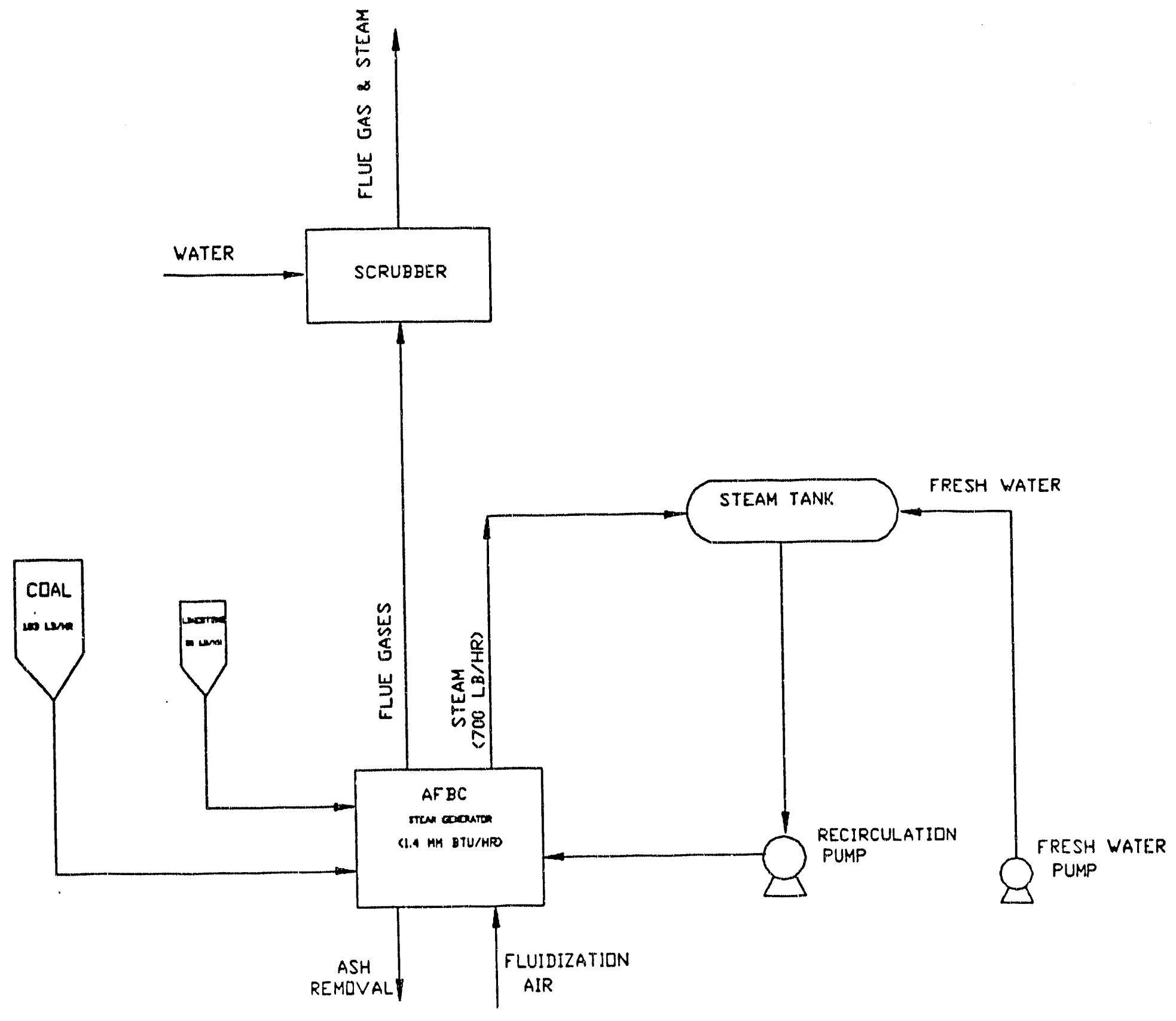

FIGURE 7: PROCESS FLOW DIAGRAM FOR THE MODIFIED AFBC SYSTEM DESIGN 
Figure 8 shows the tube layout in the fluidized bed furnace section. The bed contains four separately manifold tube bundles formed from $11 / 2$ " Sch. 80 S.S. 304 pipe. The tubes are arranged in a triangular pitch, four pass arrangement. Each tube pass is $22 \mathrm{in.}$ long, and the total heat transfer area is $14 \mathrm{ft}^{2}$. Placing the tube bundles inside the furnace will be performed by MTCI personnel after fabrication of the furnace is completed.

A Roots blower for combustion air supply was purchased in June. It consists of a Roots blower (frame type $710 \mathrm{AF}$ ) and a $10 \mathrm{HP}$ electric motor. The pulley ratio between the blower and the motor is approximately 3 to 1 . Figure 9 shows the general performance curve for the frame $710 \mathrm{AF}$ blower.

After refurbishing the Roots blower, a series of tests were performed on the blower to define its performance characteristic. Figure 10 shows the setup used for these tests. Table 1 summarizes the results of these tests. The speed of the blower was determined by using a D-C generator by Servo-Tek Products $\mathrm{C}_{0}$. with a rating of $7 \mathrm{~V}$ at $1000 \mathrm{rpm}$. A computer program using Lotus 1-2-3 was developed to calculate the flow rate through a 4" by 2" Venturi as a function of pressure drop through the Venturi.

\section{TABLE 1: RESULTS OF THE PERFORMANCE} IESTS OF THE ROOTS BLOWER

Blower RPM $=670$

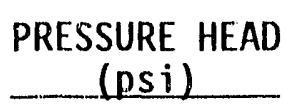

0

0.5

1.0

1.5

2.0

2.5

\section{FLOW RATE}

$(\mathrm{cfm})$

415

380

375

360

350

340

\section{AIR TEMPERATURE}

$\left({ }^{\circ} \mathrm{F}\right)$

86.2

91.0

95.3

99.0

102.4

107.7 


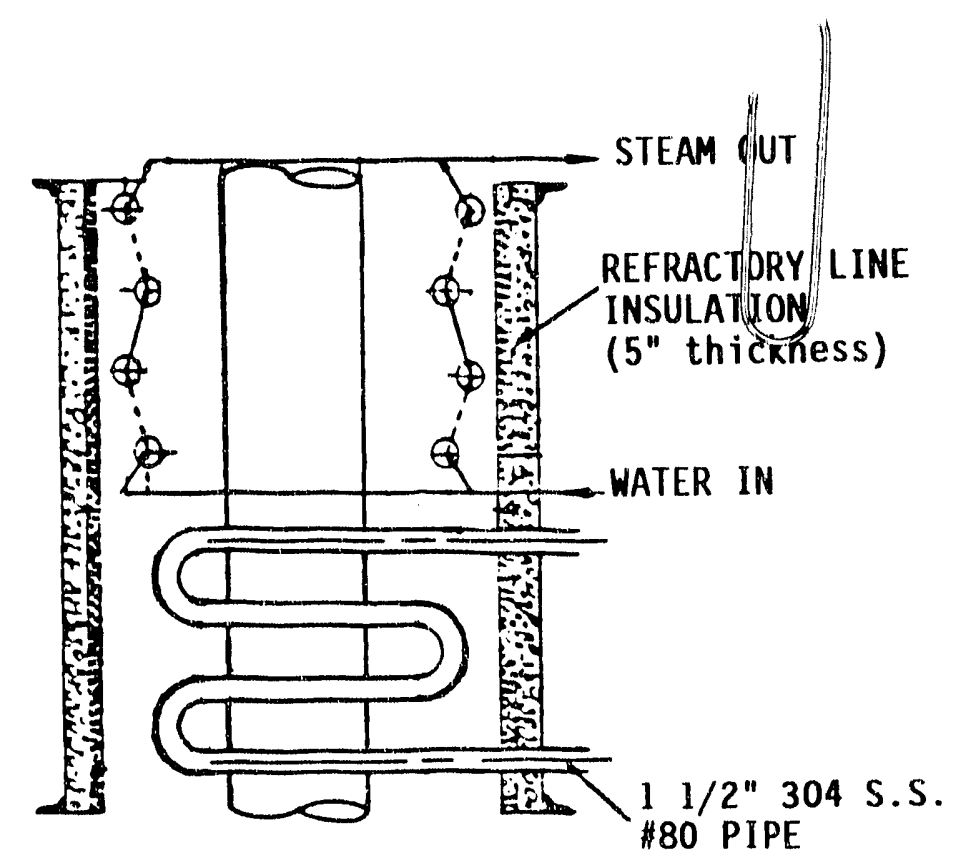

BACK SIDE VIEW

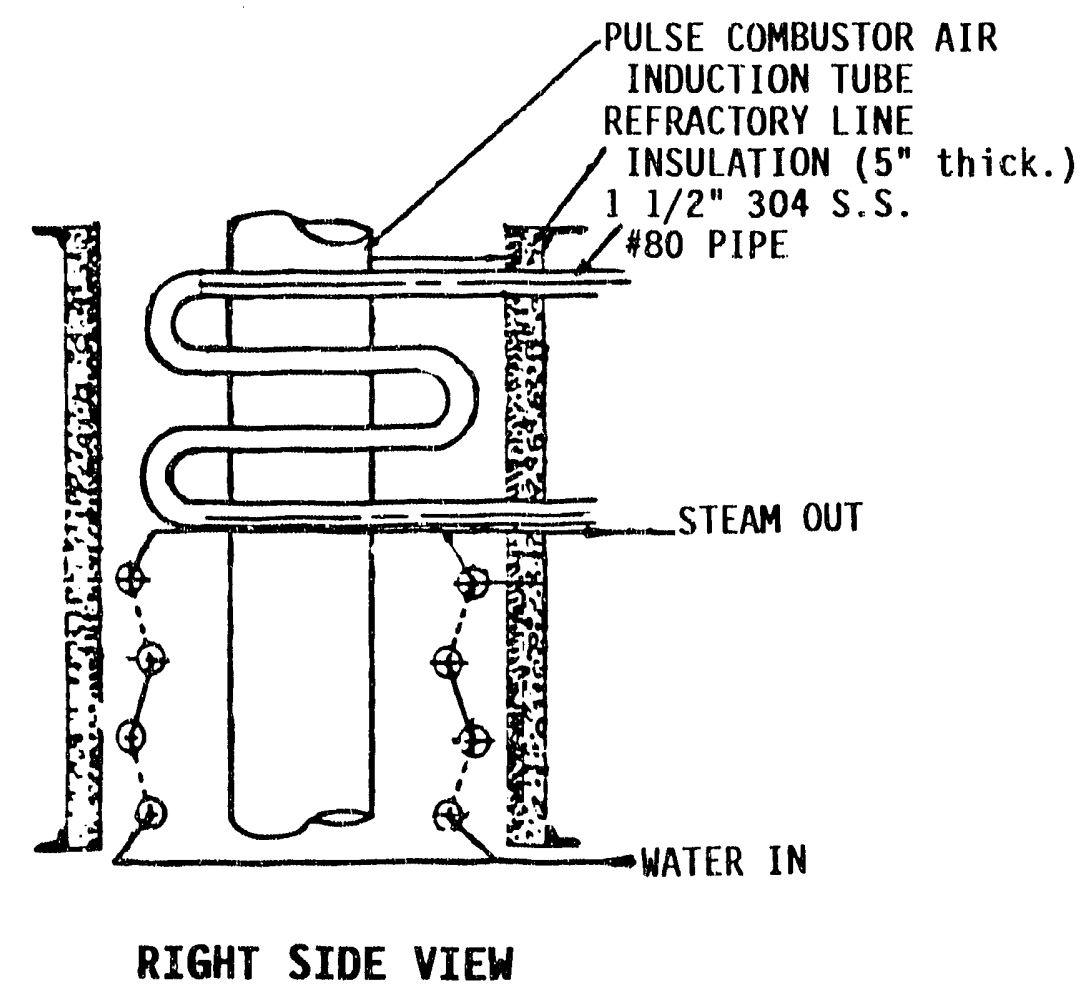

FIGURE 8: DRAWING OF THE TUBE LAYOUT IN THE BED SECTION 
Dresser Industries, InC.

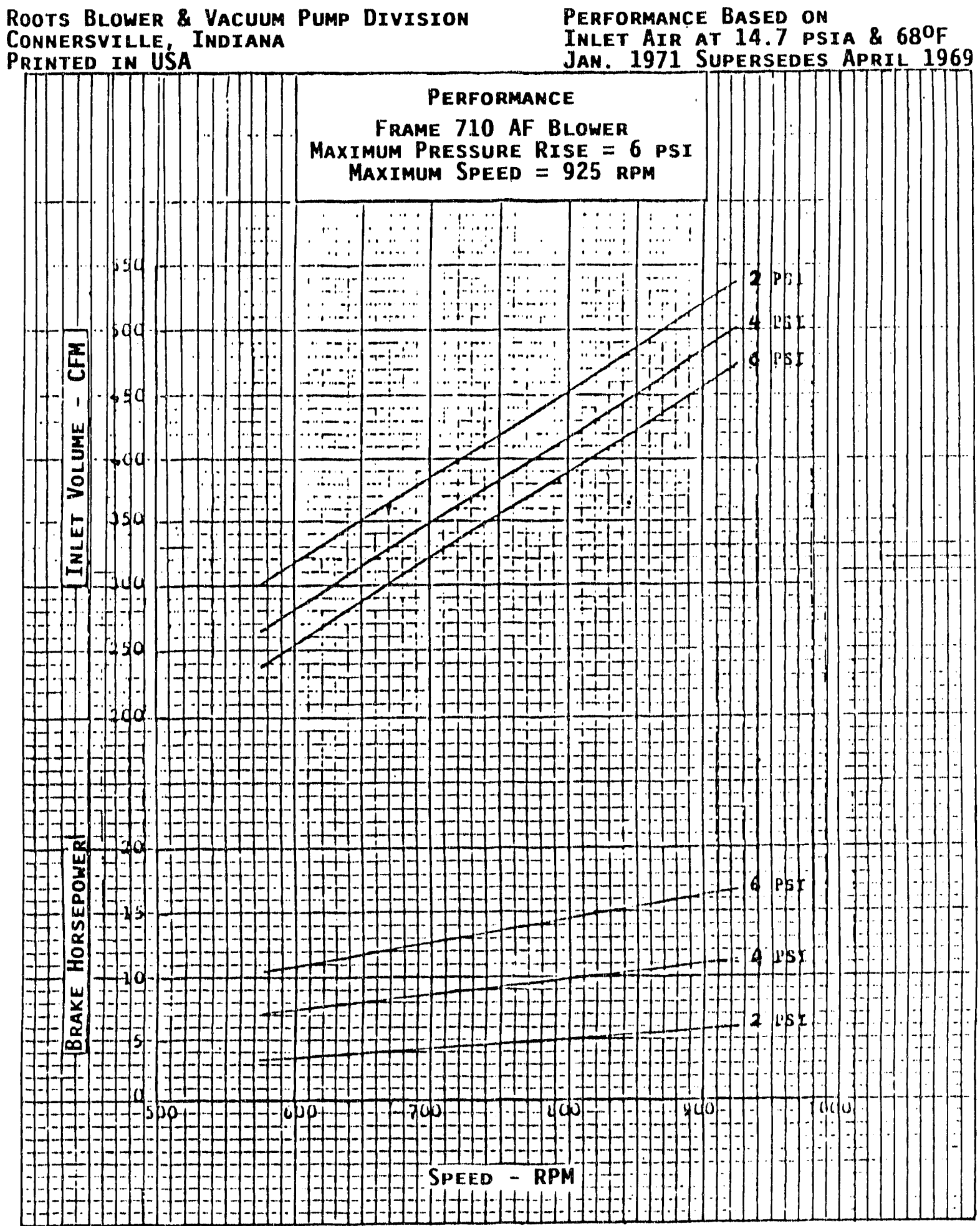

FIGURE 9: GENERAL PERFORMANCE CURVE FOR ROOTS BLOWER 


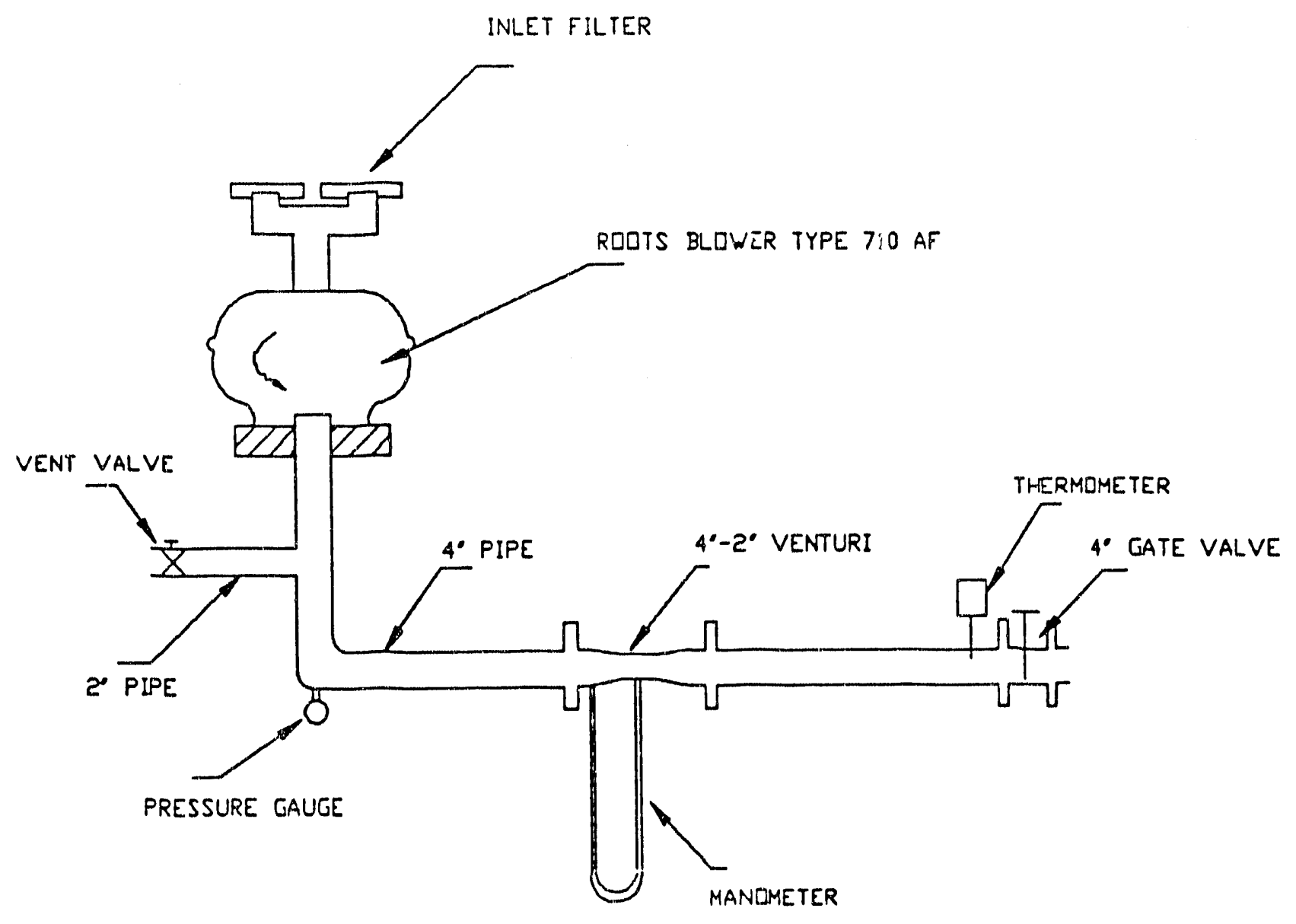

FIGURE 10: TEST SET-UP USED FOR DETERMINING THE PERFORMANCE OF THE ROOTS BLOWER 
SECTION 4.0

\section{PLANS FOR NEXT PERIOD}

It is anticipated that the procurement of most components will be completed. The outdoor site is also scheduled for completion. Installation will be initiated during the latter part of the quarter. 

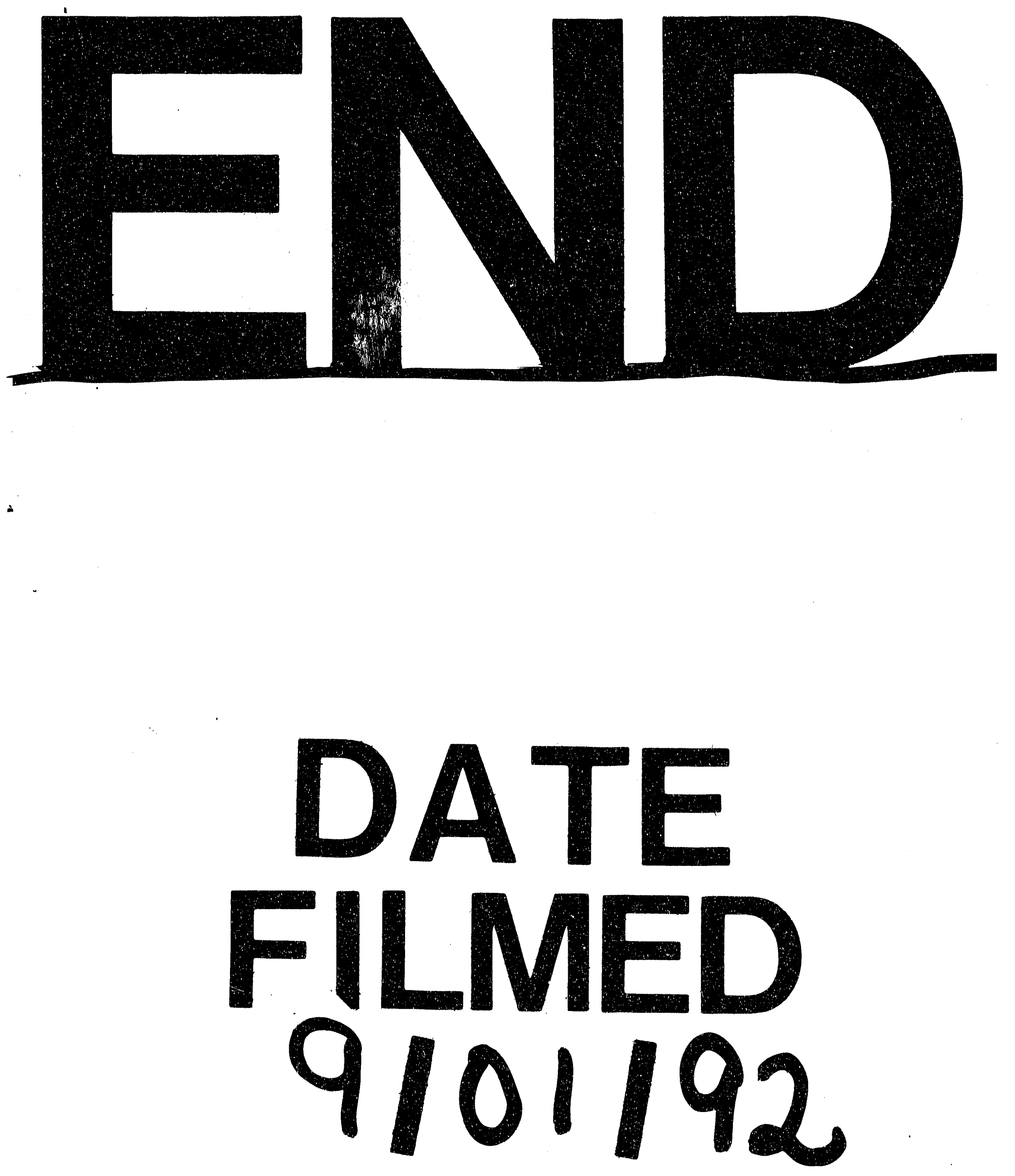
